Vol. 19(2010): 313-326.

\title{
Surface water ponding on clayey soils managed by conventional and conservation tillage in boreal conditions
}

\author{
Laura Alakukku ${ }^{1,2^{*}}$, Antti Ristolainen ${ }^{1}$, Ilkka Sarikka ${ }^{1}$ and Timo Hurme ${ }^{2}$ \\ ${ }^{1}$ MTT Agrifood Research Finland, Plant Production Research, 31600 Jokioinen, Finland \\ ${ }^{2}$ University of Helsinki, Department of Agricultural Sciences, PO Box 28,00014 University of Helsinki, Finland, \\ ${ }^{3}$ MTT Agrifood Research Finland, Services Unit, 31600 Jokioinen, Finland \\ *email: laura.alakukku@helsinki.fi
}

\begin{abstract}
Surface water ponding and crop hampering due to soil wetness was monitored in order to evaluate the effects of conservation tillage practices and perennial grass cover on soil infiltrability for five years in situ in gently sloping clayey fields. Thirteen experimental areas, each having three experimental fields, were established in southern Finland. The fields belonged to: autumn mouldboard ploughing (AP), conservation tillage (CT) and perennial grass in the crop rotation (PG). In the third year, direct drilled (DD) fields were established in five areas. Excluding PG, mainly spring cereals were grown in the fields. Location and surface area of ponded water (in the spring and autumn) as well as hampered crop growth (during June-July) were determined in each field by using GPS devices and GIS programs. Surface water ponding or crop hampering occurred when the amount of rainfall was clearly greater than the long-term average. The mean of the relative area of the ponded surface water, indicating the risk of surface runoff, and hampered crop growth was larger in the CT fields than in the AP fields. The differences between means were, however, not statistically significant. Complementary soil physical measurements are required to investigate the reasons for the repeated surface water ponding.
\end{abstract}

Key-words: crop cover, direct drilling, grass cover, ploughing, stubble cultivation, zero tillage 
Alakukku et al. Monitoring of surface water ponding on clayey soils

\section{Introduction}

In boreal areas, growing annual crops by using conventional tillage practice leaves the soil surface bare outside the growing season, i.e., from September to May. Bare soil surface increases the risk of erosion because, especially in the autumn the tilled soil has fresh, unstable shearing face, and is vulnerable to rainfall and ponding water. Out of different soils in Finland, clayey and silt soils have been evaluated to be the most susceptible to water erosion (Ministry of Agriculture and Forestry 2004). Relevant to this, the main part of the surface runoff, erosion and phosphorus loading from arable clayey fields into surface waters occurs outside the growing season during the autumn and spring runoffs (e.g. Turtola and Jaakkola 1995, Puustinen et al. 2007).

Field practices that decrease or eliminate the need for tillage and maintain crop residue on soil surface are advocated worldwide due to their potential benefits in terms of erosion control. Conservation autumn tillage practices, including shallow stubble tillage and zero tillage, and perennial grass cover are known to be advantageous regarding erosion control in clayey soils also in boreal areas as compared to conventional autumn ploughing (Skøien 1988, Turtola and Paajanen 1995, Ulén 1997, Koskiaho et al. 2002, Puustinen et al. 2005). However, contrary to the results above, Turtola et al. (2007) found that the erosion from shallow autumn stubble cultivated clayey soil (slope $2 \%$ ) was equally high to that from ploughed soil.

Changing tillage practice from mouldboard ploughing to a depth of $20-25 \mathrm{~cm}$ to shallow stubble tillage to a depth of $5-15 \mathrm{~cm}$ or zero tillage, in which only the coulters of the sowing machine disturb the soil surface, creates gradual changes in soil physical properties relevant to field hydrology. One sign of the problems in the field's hydrology is free water ponding on soil surface. Free water tends to accumulate on the surface when the local rainfall rate exceeds the soil infiltrability. Surface water ponding increases the risk of surface runoff, erosion and nutrient losses from arable fields. In fact, the share of the surface runoff from the total runoff was found to increase from $8-42 \%$ to
$36-82 \%$ when the autumn ploughing was replaced by shallow stubble cultivation or zero tilled stubble or perennial grass cover on a gently sloping clayey soil (Turtola and Jaakkola 1995, Turtola et al. 2007). The excess of surface water on soil surface and soil wetness due to the low infiltration rate and saturated hydraulic conductivity also enhance gaseous nitrogen loss (e.g. Ball et al. 2008) and hamper the crop growth due to anaerobic soil conditions, which further decrease the crop yield and the nutrient uptake (Pitkänen 1994, Alakukku et al. 2009). In addition, the low water infiltration into the soil delays field operations due to lower soil bearing capacity, which increases the risk of soil puddling and compaction due to field traffic (e.g. Hamza and Anderson 2005). Especially flat and gently sloping clayey soils are sensitive to surface water ponding.

Good water infiltration capacity and high hydraulic conductivity of wet soil prevent surface water ponding. For reduced or zero tillage, greater infiltration capacity and hydraulic conductivity have been reported compared to conventional tillage (Arshad et al. 1999, McGarry et al. 2000, Buczko et al. 2006). However, in several cases also lower hydraulic conductivity and infiltration rate under conservation tillage in fine texture soils were found (Gantzer and Blake 1978, Tebrügge and Düring 1999, Lipiec et al. 2006, Withers et al. 2007). On the other hand, some studies have shown nonsignificant differences in hydraulic properties under different practices (e.g. Starr 1990) or in the variation of infiltration properties with time (Dunn and Philips 1991).

Numerous field experiments have been conducted to evaluate the influence of conservation tillage on soil physical properties and crop growth on the plot scale. However, few studies have been carried out to investigate the spatial and temporal variation of these issues on the field scale. Changes in the physical properties of the soil, critical to soil hydrology and crop growth, are important because they clearly affect practical farming and the potential of conservation tillage to reduce erosion and nutrient loading. There is interest towards exploring the effects of different tillage practices on the field scale because a clear increase in the adop- 
Vol. 19(2010): 313-326.

tion of conservation tillage on clayey soil areas has been documented since Finland joined the EU in 1995. We addressed the question in southern Finland by monitoring the surface water ponding and crop growth in situ three times a year for five years in differently tilled gently sloping clayey soil fields. There we used surface water ponding and crop hampering due to soil wetness as indicators for a low water infiltration capacity and saturated hydraulic conductivity of wet soil.

\section{Material and methods}

\section{Experimental areas and tillage treatments}

In 2001, 13 experimental areas were established on the fields of private farmers in southern Finland.
The main selection criteria were that the field was clayey soil and that a group of three closely located fields with different tillage intensities was available (Fig. 1). Moreover, the intention was that the soil type, slope and drainage system of the closely located fields were similar to each other. The fields were subsurface drained and the mean slope was $2 \%$ or less except for the $4 \%$ slope of the ploughed field in area 6.

The topsoil properties of the fields at the beginning of the study are shown in Table 1. Yli-Halla et al. (2000) and Lilja et al. (2006) have classified the clayey soils of this area mainly as Vertic Cambisols, Eutric Cambisols and Dystic Cambisols according to the FAO (1998). The data of soil the properties was collected from farmers who had the soil analyses made according to the common protocol in Finland,i.e., by estimating the soil type and organic matter content, determined by a human sensory test. Based on the $\mathrm{pH}$ and macronutrient determinations (data not shown), the fertility of the fields was close to the average in Finland.
Fig. 1. Location of the experimental areas in southern Finland in 2001-2005. In each area, three closely situated fields were established in 2001. Direct drilled fields were included in the study in 2004.

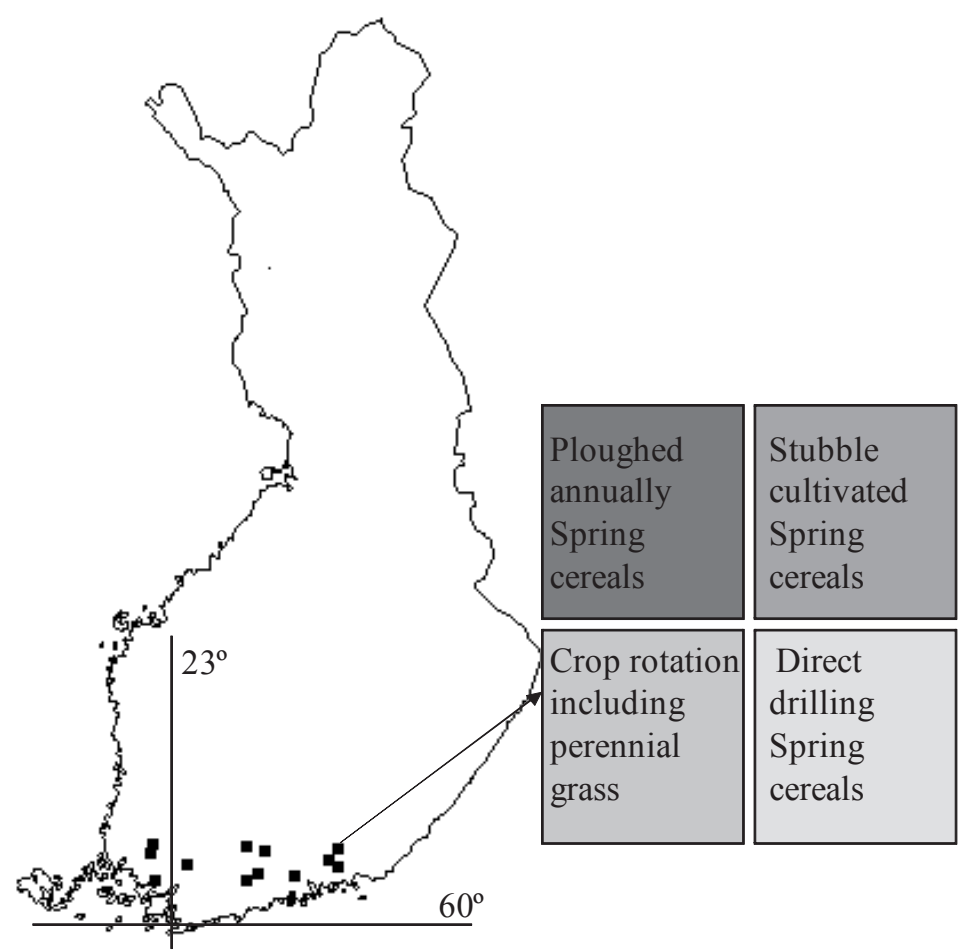


Alakukku et al. Monitoring of surface water ponding on clayey soils

Table 1. Soil type and organic matter content (SOM) for the topsoil layer of 0-20 cm of the experimental fields in the beginning of the study in 2001. Areas 1-13 are located from west to east in Fig. 1. Fields on experimental areas: AP = autumn ploughing, $\mathrm{CT}=$ conservation tillage, $\mathrm{PG}=$ perennial grass (green fallow, dried hay or hayseed) included in the crop rotation, $\mathrm{DD}=$ direct drilling (zero tillage).

\begin{tabular}{|c|c|c|c|c|c|c|c|c|}
\hline \multirow[b]{2}{*}{ Area } & \multicolumn{4}{|c|}{ Soil type } & \multicolumn{4}{|c|}{$\mathrm{SOM}^{\mathrm{a})}$} \\
\hline & $\mathrm{AP}$ & $\mathrm{CT}$ & PG & $\mathrm{DD}^{\mathrm{b})}$ & $\mathrm{AP}$ & $\mathrm{CT}$ & PG & DD \\
\hline 1 & Sandy clay & Sandy clay & Sandy clay & - & $\mathrm{rm}$ & $\mathrm{rm}$ & $\mathrm{m}$ & - \\
\hline 2 & Clayey fine sand & Clayey fine sand & Clayey fine sand & Sandy clay & $\mathrm{m}$ & $\mathrm{vm}$ & $\mathrm{m}$ & vm \\
\hline 3 & Sandy clay & Sandy clay & Sandy clay & & $\mathrm{m}$ & $\mathrm{m} / \mathrm{rm}$ & $\mathrm{m}$ & \\
\hline 4 & Clay loam & Clay loam & Sandy clay & & $\mathrm{m}$ & $\mathrm{m}$ & $\mathrm{m}$ & \\
\hline 5 & Sandy clay & Clay loam & Silt & Clay loam & $\mathrm{m}$ & $\mathrm{m}$ & $\mathrm{vm}$ & $\mathrm{rm}$ \\
\hline 6 & Loam & Loam & Loam & & $\mathrm{m}$ & $\mathrm{m}$ & $\mathrm{m}$ & \\
\hline 7 & Sandy clay & Clay loam & Clay loam & & $\mathrm{rm}$ & $\mathrm{m}$ & $\mathrm{m}$ & \\
\hline 8 & Gyttja clay & Gyttja clay & Clay loam & & $\mathrm{m}$ & $\mathrm{m}$ & $\mathrm{rm}$ & \\
\hline 9 & Silt & Clay loam & Silt & & $\mathrm{m}$ & $\mathrm{m}$ & $\mathrm{m}$ & \\
\hline 10 & Clay loam & Clay loam & Clay loam & - & $\mathrm{rm}$ & $\mathrm{rm}$ & $\mathrm{rm}$ & - \\
\hline 11 & Silty clay & Silty clay & Clay loam & & $\mathrm{m}$ & $\mathrm{m}$ & $\mathrm{rm}$ & \\
\hline 12 & Silty clay & Silty clay & Silty clay & & $\mathrm{rm}$ & $\mathrm{m} / \mathrm{rm}$ & $\mathrm{rm}$ & \\
\hline 13 & Sandy clay & Sandy clay & Sandy clay & Silt & $\mathrm{m}$ & $\mathrm{m}$ & $\mathrm{m}$ & $\mathrm{m}$ \\
\hline
\end{tabular}

${ }^{\mathrm{a} S O M}$ for vm less than $0.03 \mathrm{~g} \mathrm{~g}^{-1}, \mathrm{~m}: 0.03-0.059 \mathrm{~g} \mathrm{~g}^{-1}$, and rm: $0.06-0.119 \mathrm{~g} \mathrm{~g}^{-1}$

$\mathrm{b}^{\mathrm{b}}$-: data not available; empty cells: no DD field in the area

In 2001, three experimental fields with different tillage intensities were established in each selected area. The treatments of experimental fields were: annual autumn mouldboard ploughing (AP), conservation tillage (CT), and temporal zero tillage including perennial grass (green fallow, dried hay or hayseed) that was included in the crop rotation (PG). In 2004, annually direct drilled (DD, zero tillage) fields in areas 1, 2, 5, 10 and 13 were included in the study because direct drilling of spring cereals started to increase rapidly in Finland during the study. In the same year, two additional CT fields (in areas 5 and 9) were included in the study. The CT treatment represented annual autumn stubble cultivation with a cultivator, a s-tine harrow, a rotary spade harrow or a disc harrow. In years 2001-2003, the plant cover for most of the PG fields was perennial grass.

The original plan was that the AP and CT treatments would be carried out in the same fields in years 2000-2004. The CT treatment had been started in 1999 in areas 1, 8, and 12, and started in 2001 in areas 7 and 11. In other areas, CT had been carried out for several years before the study.
In areas 2 and 13, the AP treatment was supposed to be established by ploughing conservation tillage fields but the farmers decided to continue the current tillage practices until autumn 2003 (Table 2). After the rainy summer and autumn of 2004, some of the CT fields were ploughed (Table 2).

\section{Cultivated crops and weather conditions}

Mainly spring sown crops barley (Hordeum vulgare L.), wheat (Triticum aestivum L.), oats (Avena sativa L.) and spring oilseed rape (Brassica rapa L.) were cultivated in the annually tilled fields. Annual crops were grown in the same fields five years before the present study, excluding the AP fields in areas 2 and 12, and the CT fields in areas 8 and 12, in which perennial grass was grown in rotation. Linseed (Linum usitatissimum) was grown in area 2 in 2002 (CT), 2003 (AP, CT, PG) and 2004 (DD), and camelina (Camelina sativa) in area 1 (AP) in 2005. Winter cereals were grown occasionally (Table 2). During the first three years, perennial grass was 
Vol. 19(2010): 313-326.

Table 2. Tillage of the fields $(\mathrm{AP}=$ autumn ploughing, $\mathrm{CT}=$ conservation tillage, $\mathrm{PG}=$ perennial grass included in the crop rotation, $\mathrm{DD}=$ direct drilling) of experimental areas in autumns 2000-2004. Observations were carried out in spring, summer and autumn of years 2001-2005. Tillage: $\mathrm{P}=$ ploughing, $\mathrm{SC}=$ stubble cultivation, $\mathrm{NTG}=$ no tillage, grass cover, NTS = no tillage, stubble cover.

\begin{tabular}{|c|c|c|c|c|c|c|c|c|c|c|c|c|c|c|}
\hline \multirow{2}{*}{ Year } & \multirow{2}{*}{ Tillage } & \multicolumn{13}{|c|}{ Area } \\
\hline & & 1 & 2 & 3 & 4 & 5 & 6 & 7 & 8 & 9 & 10 & 11 & 12 & 13 \\
\hline \multirow[t]{3}{*}{2000} & AP & $\mathrm{SC}$ & NTS & $\mathrm{P}^{\mathrm{a}}$ & $\mathrm{SC}$ & $P$ & $P$ & $P$ & $P$ & $P$ & $P$ & $\mathrm{P}$ & $P$ & $\mathrm{SC}$ \\
\hline & $\mathrm{CT}$ & $\mathrm{SC}$ & $\mathrm{SC}$ & $\mathrm{SC}$ & $\mathrm{SC}$ & $\mathrm{SC}$ & $\mathrm{SC}$ & $\mathrm{P}$ & $\mathrm{SC}$ & $\mathrm{SC}$ & $\mathrm{SC}$ & $\mathrm{P}$ & $\mathrm{SC}$ & $\mathrm{SC}$ \\
\hline & PG & NTG & NTG & $\mathrm{P}$ & NTG & NTG & NTG & NTG & NTG & $\mathrm{SC}$ & $\mathrm{P}$ & NTG & NTG & NTG \\
\hline \multirow[t]{3}{*}{2001} & $\mathrm{AP}$ & $\mathrm{P}$ & NTS & $\mathrm{P}$ & $\mathrm{P}$ & $\mathrm{P}$ & $\mathrm{P}$ & $\mathrm{P}$ & $\mathrm{P}$ & $\mathrm{P}$ & $\mathrm{P}$ & $\mathrm{P}$ & $\mathrm{P}$ & NTS \\
\hline & $\mathrm{CT}$ & $\mathrm{SC}$ & NTS & $\mathrm{SC}$ & NTS & $\mathrm{SC}$ & $\mathrm{SC}$ & $\mathrm{SC}$ & $\mathrm{SC}$ & $\mathrm{SC}$ & $\mathrm{SC}$ & $\mathrm{SC}$ & $\mathrm{SC}^{\mathrm{a}}$ & NTS \\
\hline & PG & NTG & NTG & NTG & NTG & NTG & NTG & NTG & NTG & $\mathrm{P}$ & NTG & NTG & NTG & NTG \\
\hline \multirow[t]{3}{*}{2002} & AP & $P$ & NTS & $\mathrm{P}$ & $\mathrm{P}$ & $\mathrm{P}$ & $\mathrm{P}$ & $\mathrm{P}$ & $\mathrm{P}$ & $\mathrm{P}^{\mathrm{a} / \mathrm{F}}$ & $\mathrm{P}$ & $\mathrm{SCb}$ & $\mathrm{SC}^{\mathrm{b}}$ & $\mathrm{SCb}$ \\
\hline & $\mathrm{CT}$ & SC & NTS & $\mathrm{SC}$ & $\mathrm{NTS}^{\mathrm{b}}$ & $\mathrm{SC}$ & $\mathrm{SC}$ & $\mathrm{SC}^{\mathrm{b}, \mathrm{c}}$ & $\mathrm{SC}$ & $\mathrm{SC}$ & $\mathrm{SC}$ & $\mathrm{SC}$ & $\mathrm{SC}$ & $\mathrm{SC}$ \\
\hline & PG & NTG & NTS & NTG & NTG & NTG & NTG & NTG & NTG & $\mathrm{P}$ & $\mathrm{SC}$ & NTG & NTG & NTG \\
\hline \multirow[t]{4}{*}{2003} & AP & $\mathrm{P}$ & $\mathrm{P}$ & NTG & & $P$ & $P$ & $\mathrm{P}$ & $\mathrm{P}$ & $\mathrm{P}$ & $\mathrm{P}$ & $\mathrm{P}$ & $\mathrm{P}$ & $\mathrm{P}$ \\
\hline & $\mathrm{CT}$ & $\mathrm{SC}$ & $\mathrm{P}$ & $\mathrm{P}$ & & $\mathrm{SC}$ & $\mathrm{SC}$ & $\mathrm{SC}$ & $\mathrm{SC}$ & $\mathrm{SC}$ & $\mathrm{SC}$ & $\mathrm{SC}$ & $\mathrm{SC}$ & $\mathrm{SC}$ \\
\hline & PG & NTG & $\mathrm{P}^{\mathrm{a}}$ & $\mathrm{P}$ & & NTG & $\mathrm{P}$ & NTG & $\mathrm{Pa}$ & $\mathrm{P}$ & NTG & NTG & NTG & NTG \\
\hline & DD & NTS & NTS & & & NTS & & & & & NTS & & & $\mathrm{NTS}^{\mathrm{a}}$ \\
\hline \multirow[t]{4}{*}{2004} & $\mathrm{AP}$ & $\mathrm{P}$ & $\mathrm{P}$ & NTG & & $\mathrm{P}$ & $\mathrm{P}$ & $\mathrm{P}$ & $\mathrm{P}$ & $\mathrm{SC}$ & $\mathrm{P}$ & & & $\mathrm{P}$ \\
\hline & $\mathrm{CT}$ & $\mathrm{SC}$ & NTS & $\mathrm{P}$ & & $\mathrm{SC}$ & $\mathrm{P}$ & NTS & $\mathrm{SC} / \mathrm{P}$ & $\mathrm{P}$ & $\mathrm{SC}$ & & & NTS \\
\hline & PG & $\mathrm{P}^{\mathrm{a}}$ & $\mathrm{F}^{\mathrm{d} / \mathrm{NTG}}$ & $\mathrm{P}$ & & NTG & $\mathrm{P}$ & NTG & $\mathrm{SC}$ & $\mathrm{P}$ & NTS/P & NTG & NTG & NTG \\
\hline & DD & NTS & NTS & & & NTS & & & & & NTS & & & NTS \\
\hline
\end{tabular}

${ }^{\mathrm{a}}$ sown for winter wheat or rye

${ }^{\mathrm{b}}$ soil was too dry for plowing or stubble cultivation in autumn

'spring tillage

${ }^{\mathrm{d}} \mathrm{F}=$ bare, stubble or annual grass fallow

cultivated in the PG fields. In areas 5, 7, 11, 12 and 13, perennial grass was grown in the PG fields also in years 2004 and 2005.

The fields were cultivated following common farming practices in Finland. For spring sown crops it usually meant autumn tillage (AP: ploughing to a depth of 20-25 cm, CT: stubble cultivation (10-15 $\mathrm{cm})$, DD: zero tillage), seedbed preparation (AP, CT) before sowing, fertilizing and sowing with a combined drill (AP, CT, DD), herbicide spraying in summer, and harvesting. The PG treatment was cut (green fallow) or harvested (for hay or seed) annually.

The local weather conditions and soil moisture status were evaluated by utilizing the data of the closest weather stations of the Finnish Meteorological Institute and the closest groundwater stations of the Finnish Environment Institute (Fig.
2). The soil moisture status was obtained based on the depth from the soil surface to the groundwater table. During the experimental period, the mean temperature was close to the long-term average or higher in April, May, and from July to September. Except year 2002, the mean temperature of June was lower than the long-term average (data not shown). The precipitation was clearly less than that on average, i.e. in years 1971-2000, in autumn 2002 and in the beginning of the year 2003 (Fig. 2a). Thus, the groundwater table was clearly lower than the average from the end of the year 2002 to the beginning of the year 2004 (Fig. 2b). Even though the annual precipitation in years 2004 and 2005 was larger than the long-term average, the beginning of the year 2004 (January-April) was again dry. The growing season (May-August) of 2004 was exceptionally rainy and the precipita- 
Alakukku et al. Monitoring of surface water ponding on clayey soils

tion was $38-100 \%$ higher than on average (Fig. 2a). In 2004, September and December were also rainy. The distribution of rainfall was uneven, and in January 2005, the precipitation was larger by
$82-147 \%$ than on average. In the growing season of 2005, only the precipitation of August was clearly larger (by 70-130\%) than the long-term average.

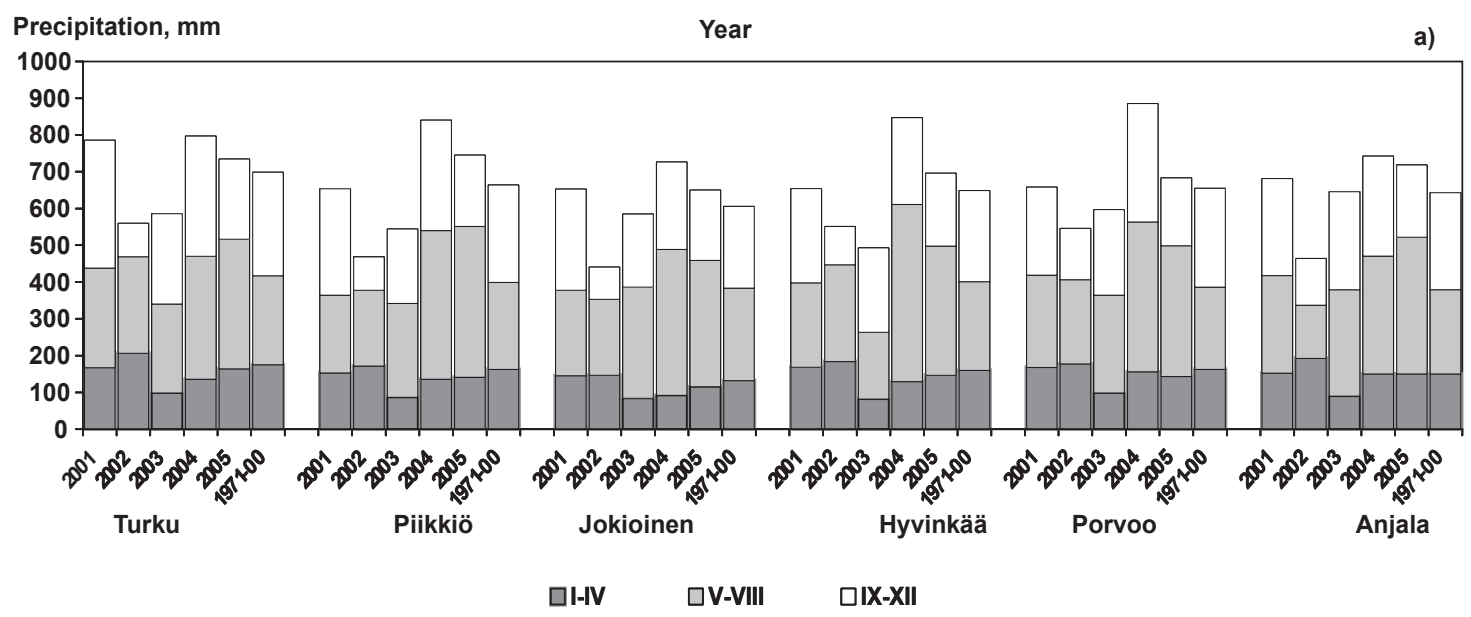

Annual value-long-term mean, $\mathrm{cm}$

b)

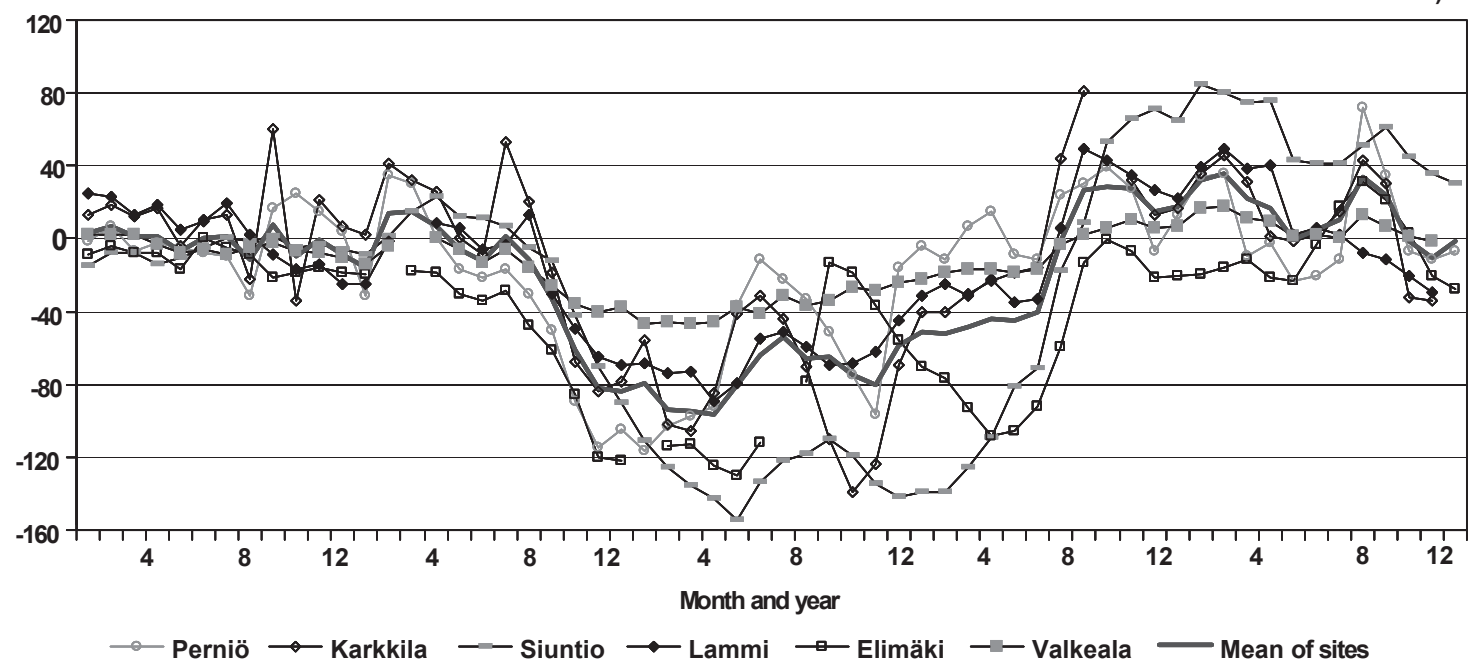

Fig. 2. (a) Annual precipitation as a sum of three periods: January to April (I-IV), May to August (V-VIII) and September

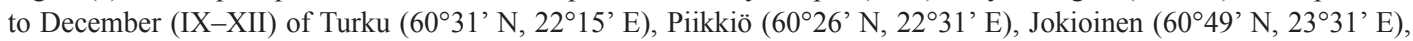

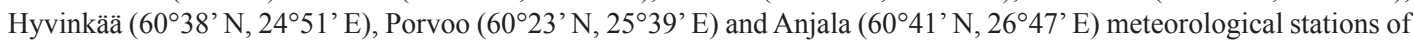
the Finnish Meteorological Institute in 2001-2005, and the mean of years 1971-2000 according to Drebs et al. (2002). (b) The variation of the distance to the groundwater table from the soil surface at Perniö $\left(60^{\circ} 12^{\prime}\right.$ N, $23^{\circ} 07^{\prime}$ E), Karkkila $\left(60^{\circ} 32^{\prime} \mathrm{N}, 2^{\circ} 12^{\prime} \mathrm{E}\right)$, Siuntio $\left(60^{\circ} 08^{\prime} \mathrm{N}, 2^{\circ} 13^{\prime} \mathrm{E}\right)$, Lammi $\left(61^{\circ} 05^{\prime} \mathrm{N}, 25^{\circ} 00^{\prime} \mathrm{E}\right)$, Elimäki $\left(60^{\circ} 43^{\prime} \mathrm{N}, 2^{\circ} 27^{\prime} \mathrm{E}\right)$ and Valkeala $\left(60^{\circ} 56^{\prime} \mathrm{N}, 26^{\circ} 48^{\prime} \mathrm{E}\right)$ in 2001-2005. The difference between the monthly and long-term average values is presented (annual data from the Finnish Environment Institute and long-term average from Soveri et al. (2001)). 
Vol. 19(2010): 313-326.

\section{Field area covered or hampered by ponded water}

The share of the field area covered by ponded water was monitored in the springs (before tillage) and autumns of 2001-2005 except in autumn 2002 when the soil was very dry (Fig. 2b). The observations were performed outside the growing season because in Finnish conditions most of the surface runoff has been found to occur in the spring and autumn (Turtola and Jaakkola 1995, Puustinen et al. 2007). The ground with a uniform cover of water was classified as a puddle area, and the ground having water in the depressions of rough soil surface was classified as a depressional water area. In springs and autumns of 2001-2003, both puddle and depressional water areas were observed. In 2004-2005, only the areas covered by puddles were recoreded.

In the growing seasons of 2001 and 2003-2005, the proportion of the field areas hampered by soil wetness were determined in June-July before the spring sown crop came into ear, because the plants are sensitive to excess wetness in the early developmental stages (Stẹpniewski and Łabuda 1989). Year 2004 was exceptional due to excess wetness, and the observations were made therefore later, after the crop had ripened. If heavy rains and surface water ponding were observed in any experimental area, the size of the area where crop hampered due to soil wetness was determined based on the color/ ripening differences (from light green to yellow color/forced ripening in an overwet growing place compared to dark green/still growing crop in a permeable place). The places covered or hampered by surface water were observed by walking across the field from bottom headland to upper headland with a distance of 40-50 m between the contiguous routes. For consistency, only two persons made the field observations, the first person in years 20012003 and the second one in years 2004-2005.

The location and surface area of ponded water and hampered crop was determined with GPS devices by saving the readings given by the device on the edge of the places that were covered by hampering or surface water. The field data was corrected after recordings by using the differential correction which typically yields the accuracy of $0.5-1 \mathrm{~m}$. The field surveys were carried out with Trimble ProXR (2001-03, Trimble Navigation Ltd.), Garmin eTrex (only spring 2003, Garmin Ltd.) and Trimble GeoXT (2004-05, Trimble Navigation Ltd.) GPS receivers. The field data was analyzed and stored using GIS programs (Pathfinder 2.70 (2001-03), Pathfinder office 3.10 (2004-05) (Trimble Ltd.) and ArcView 3.2 (ESRI Inc.)). The ratio of the surface area with water ponded on ground or the area with hampered crop growth to the total field area was calculated.

\section{Statistical analyses}

The results of years 2001-2003 and of years 20042005 were analyzed separately because only during the first three years, the AP, CT and PG fields were tilled according to the original plan. The results of areas 2 and 13 were, however, not included in the data because the fields intended for AP were not mouldboard ploughed (Table 2). The results from years 2001-2003 consist of the total relative areas covered by puddles and depressional water with respect to the total field area. For each year, the results of different observation times (spring, growing season, autumn) were treated separately. The data of spring 2001 was analyzed as a randomized complete block design. In this analysis the experimental area was considered as a blocking factor and the tillage as a treatment factor. The analysis was performed using a nonparametric simulation based approach with simulation size 100000 (Berry 1997). The nonparametric method was used because of the low proportions of the observed surface ponded area. For the other observations in 2001-2003, the surface water ponding was detected only in some fields due to the drought, and the data was not analyzed statistically.

In 2004, six direct drilled and two additional conservation tillage fields joined the study (Table 2 ). Some of the farmers also changed the tillage practice, especially after the rainy growing season of 2004 (Fig. 2, Table 2). Therefore the results of years 2004 and 2005 were analyzed together, and 
Alakukku et al. Monitoring of surface water ponding on clayey soils

only the results of fields having the same tillage treatment in both years (see Table 2) were included in the data. The results of the relative area of puddles to the total field area were analyzed by utilizing a randomized complete block design with repeated measurements. The tillage treatment was considered as the treatment factor, the experimental area as the blocking factor, and the year as the repeated measure. The individual fields within each area and the tillage treatment constituted the experimental unit. Thus the statistical model became:

$Y_{j k l m j}=\mu+$ area $_{i}+$ tillage $_{j}+$ area $\times$ tillage $_{i j}+$ field $_{k(i j)}+$ year $_{l}+$ area $\times$ year ${ }_{i l}+$ tillage $\times$ year $_{j l}+$ area $\times$ tillage $\times$ year $_{i j l}+\varepsilon_{i j k l m}$

(1)

In equation (1), $\mu$ is a constant. The tillage, year $_{l}$ and tillage $\times$ year ${ }_{j l}$ are fixed effects. The area $_{i}$, area $\times$ tillage $_{i j}$, area $\times$ year $_{i l}$ and area $\times$ tillage $\times y e a r_{i j l}$, are random effects. The field $_{k(i j)}$ is also a random effect and it identifies an individual field within area $i$ and tillage $j$. The $\varepsilon_{i j k l m}$ is the error term. The

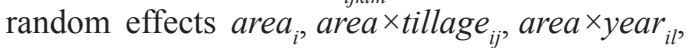
area $\times$ tillage $\times$ year $_{i j l}$, field $d_{k(i j)}$ and $\varepsilon_{i j k l m}$ were all assumed to be mutually independent and normally distributed with zero means and variances $\sigma^{2}, \sigma^{2}$ at, $\sigma_{\text {ay }}^{2}, \sigma_{\text {aty }}^{2}, \sigma_{\mathrm{f}}^{2}$ and $\sigma_{\varepsilon}^{2}$, respectively (Kuehl 2000). The arcsine transformation was used to normalize the skewed data. The estimated means were then transformed back to the original scale of measurement. REML was used as the estimation method and degrees of freedom were calculated using the Kenward-Roger method (Kenward and Roger 1997). Modelling was performed with the MIXED procedure of SAS version 9.1.3 (SAS Institute Inc., Cary, NC, USA).

\section{Results}

\section{Surface water ponding}

An example of the results from one experimental area is given in Fig. 3. Table 3 shows the results for the share of the total area of ponded water during the period of 2001-2005 (puddles and depressional water in years 2001-2003, and puddles in 2004-2005). During the period from autumn 2001 to spring 2004, the mean share of the ponding area was larger in stubble cultivated fields than in ploughed or grass

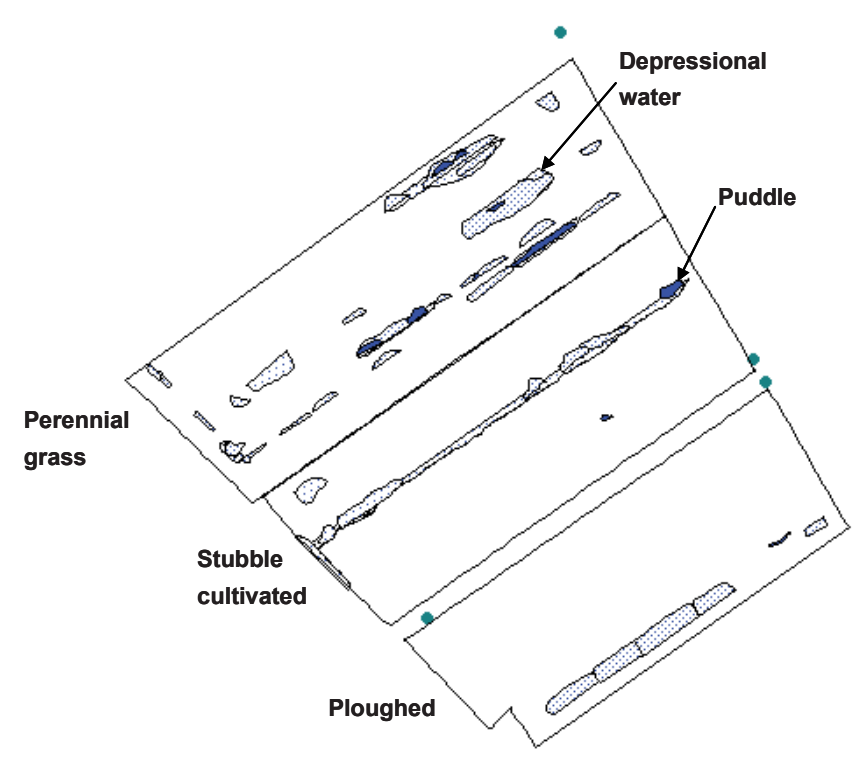

Fig. 3. Areas covered by puddles and depressional water in the fields of area 4 in 2001-2002. 
Vol. 19(2010): 313-326.

Table 3. Mean area of the ponded surface water on ground (sum of the areas of puddles and depressional water in 2001-03, and the areas of puddles in 2004-05) with respect to the total field area (\%) in differently tilled fields in springs and autumns 2001-2005. Tillage treatments repeated annually in 2001-2003 and in 2004-2005: AP = autumn ploughing, CT = conservation tillage, $\mathrm{PG}=$ perennial grass in crop rotation (the results of zero tillage years were used in analyzes), $\mathrm{DD}=$ direct drilling (zero tillage). For years 2001-2003, the means presented are arithmetic means, and for years 2004-2005, the means presented are model based mean estimates transformed back to the original scale of measurement. The CI's are $95 \%$ confidence intervals for the means.

\begin{tabular}{|c|c|c|c|c|c|c|c|c|c|c|}
\hline & \multicolumn{3}{|c|}{ April-May 2001} & \multicolumn{3}{|c|}{ April 2002} & \multicolumn{4}{|c|}{ April-May 2003} \\
\hline & $\mathrm{AP}$ & $\mathrm{CT}$ & PG & $\mathrm{AP}$ & CT & PG & $\mathrm{AP}$ & & $\mathrm{CT}$ & PG \\
\hline Mean & 2.4 & 1.6 & 0.4 & 0.3 & 0.5 & 0.05 & 0.2 & & 1.1 & 0.2 \\
\hline Median & 0.1 & 0.2 & 0 & 0 & 0 & 0 & 0 & & 0 & 0 \\
\hline Min-Max & $0-24$ & $0-9.7$ & $0-2.1$ & $0-3.0$ & $0-4.1$ & $0-0.4$ & $0-1$. & & $0-10$ & $0-1.1$ \\
\hline $\mathrm{n} / \mathrm{N}^{\mathrm{a}}$ & $7 / 11$ & $8 / 11$ & $3 / 11$ & $2 / 10$ & $3 / 10$ & $2 / 10$ & $2 / 1$ & & $2 / 10$ & $3 / 10$ \\
\hline Pair & $\mathrm{AP} / \mathrm{CT}$ & $\mathrm{CT} / \mathrm{PG}$ & $\mathrm{AP} / \mathrm{PG}$ & & & & & & & \\
\hline \multirow{3}{*}{$p$-value } & 0.84 & 0.44 & 0.84 & & & & & & & \\
\hline & \multicolumn{3}{|c|}{ September 2001} & \multicolumn{3}{|c|}{ Autumn $2002^{\mathrm{b}}$} & \multicolumn{4}{|c|}{ November 2003} \\
\hline & AP & $\mathrm{CT}$ & PG & AP & $\mathrm{CT}$ & PG & $\mathrm{AF}$ & & $\mathrm{CT}$ & PG \\
\hline Mean & 0.03 & 0.5 & 0.1 & & & & 0 & & 0.01 & 0.1 \\
\hline Median & 0 & 0 & 0 & & & & 0 & & 0 & 0 \\
\hline Min-Max & $0-0.2$ & $0-4.0$ & $0-0.8$ & & & & & & $0-0.1$ & $0-0.8$ \\
\hline \multirow[t]{3}{*}{$\mathrm{n} / \mathrm{N}$} & $2 / 11$ & $4 / 11$ & $2 / 11$ & & & & $0 / 1$ & & $1 / 11$ & $3 / 11$ \\
\hline & \multicolumn{4}{|c|}{ April 2004} & Mean & \multicolumn{4}{|c|}{ April-May 2005} & Mean \\
\hline & AP & $\mathrm{CT}$ & PG & DD & $2004^{c}$ & AP & $\mathrm{CT}$ & PG & DD & $2005^{\mathrm{c}}$ \\
\hline Mean & 0.002 & 0.000 & 0.000 & 0.02 & 0.002 & 0.2 & 3.2 & 2.7 & 0.1 & 1.1 \\
\hline $\mathrm{CI}$ & $0-0.02$ & $0-0.02$ & $0-0.01$ & $0.001-0.07$ & $0-0.01$ & $0-1.6$ & $0.3-9.0$ & $0.3-7.5$ & $0-2.2$ & $0.3-2.6$ \\
\hline $\mathrm{n} / \mathrm{N}$ & $1 / 12$ & $1 / 5$ & $0 / 7$ & $3 / 6$ & & $6 / 12$ & $3 / 5$ & $4 / 6$ & $2 / 6$ & \\
\hline Pair ${ }^{\mathrm{d}}$ & & $\mathrm{AP} / \mathrm{CT}$ & $\mathrm{AP} / \mathrm{PG}$ & $\mathrm{AP} / \mathrm{DD}$ & & & $\mathrm{AP} / \mathrm{CT}$ & $\mathrm{AP} / \mathrm{PG}$ & $\mathrm{AP} / \mathrm{DD}$ & \\
\hline \multirow[t]{3}{*}{$p$-value } & & 0.54 & 0.46 & 0.19 & & & 0.07 & 0.09 & 0.87 & \\
\hline & \multicolumn{4}{|c|}{ November 2004} & & \multicolumn{4}{|c|}{ October-November 2005} & \\
\hline & AP & $\mathrm{CT}$ & PG & DD & & AP & $\mathrm{CT}$ & PG & DD & \\
\hline Mean & 1.0 & 1.9 & 0.05 & 0.8 & 0.8 & 0.1 & 1.0 & 0.02 & 1.7 & 0.5 \\
\hline $\mathrm{CI}$ & $0.1-2.8$ & $0.2-5.6$ & $0-1.4$ & $0-3.4$ & $0.1-2.0$ & $0-0.8$ & $0.01-3.4$ & $0-0.7$ & $0.3-4.3$ & $0.05-1.3$ \\
\hline $\mathrm{n} / \mathrm{N}$ & $9 / 11$ & $4 / 5$ & $2 / 3$ & $3 / 5$ & & $5 / 12$ & $3 / 5$ & $0 / 6$ & $5 / 6$ & \\
\hline
\end{tabular}

${ }^{a}$ number of fields having surface ponded water (n)/total number of experimental fields (N)

bno surface ponded water in dry conditions

cbetween years comparison: in spring $p=0.0008$, and in autumn $p=0.53$

in spring, interaction between the year and the tillage treatment $p=0.10$, and in autumn $p=0.15$ 


\section{Alakukku et al. Monitoring of surface water ponding on clayey soils}

covered fields (Table 3). However, surface water was observed only in a few fields because of the dry conditions in southern Finland (Fig. 2). During the period from autumn 2001 to autumn 2003, surface water ponding was observed altogether in 8 out of 11 experimental areas (Table 3). For each different treatment (AP, CT, PG), the ponding was observed in five fields. More than once in the same field, it was observed for 1, 3 and 4 ploughed, stubble cultivated and perennial grass fields, respectively.

Since the more rainy season starting in summer 2004 (Fig. 2), puddles were found in several fields, and the share of puddled area was clearly larger than in earlier years (Table 3). During autumns 2004 and 2005, and spring 2005, the puddles were observed at $92,100,67$ and $83 \%$ of the ploughed, stubble cultivated, perennial grass and direct drilled fields, respectively. More than once in the same field the puddles were observed at 58,60, 17 and $50 \%$ of the ploughed, stubble cultivated, perennial grass and direct drilled fields, respectively.
In autumns 2004 and 2005, and in spring 2005, the mean share of puddles from the total field area was larger in the stubble cultivated fields than in the ploughed or grass covered fields (Table 3). In spring 2005, the difference in the share of the puddled area between the CT and AP treatments was nearly statistically significant $(p=0.07)$. The results of the direct drilled treatment were only indicative because the zero tillage cultivation had been carried out only for a few years in the same fields.

\section{Crop hampering}

In addition to direct measurements of surface puddle areas, the effect of tillage treatment on surface water ponding during the growing season was observed by determining the share of crop hampered by soil wetness (Table 4). In the exceptionally rainy growing season of 2004 (Fig. 2), crop hampered on each

Table 4. Area of the field ground having crop hampering due to soil wetness as a ratio of the total field area (\%) in differently tilled fields during growing seasons 2001 and 2003-2005. In 2002, no crop hampering was observed. Tillage treatments repeated annually in 20012003 and in 2004-2005: AP = autumn ploughing, CT = conservation tillage, PG = perennial grass in crop rotation (the results of zero tillage years were used in analyzes), $\mathrm{DD}=$ direct drilling (zero tillage). For years 2001-2003, the means presented are arithmetic means, and for years 2004-2005, the means presented are model based mean estimates transformed back to the original scale of measurement. The CI's are $95 \%$ confidence intervals for the means.

\begin{tabular}{|c|c|c|c|c|c|c|c|c|c|c|}
\hline & \multicolumn{4}{|c|}{ July 2001} & & \multicolumn{4}{|c|}{ June-July 2003} & \\
\hline & AP & $\mathrm{CT}$ & PG & & & AP & $\mathrm{CT}$ & PG & & \\
\hline Mean & 0.9 & 1.2 & 3.0 & & & 0.01 & 1.2 & 0 & & \\
\hline Median & 0 & 0 & 0 & & & 0 & 0 & 0 & & \\
\hline Min-Max & $0-2.5$ & $0-4.7$ & $0-12$ & & & $0-0.1$ & $0-10$ & & & \\
\hline \multirow[t]{3}{*}{$\mathrm{n} / \mathrm{N}^{\mathrm{a}}$} & $2 / 5$ & $2 / 5$ & $1 / 5$ & & & $1 / 9$ & $2 / 9$ & $0 / 9$ & & \\
\hline & \multicolumn{4}{|c|}{ September 2004} & Mean & \multicolumn{4}{|c|}{ June-July 2005} & Mean \\
\hline & AP & $\mathrm{CT}$ & PG & DD & 2004 & $\mathrm{AP}$ & $\mathrm{CT}$ & PG & DD & \\
\hline Mean & 1.5 & 3.9 & 1.3 & 2.6 & $2.2^{\mathrm{b}}$ & 0.2 & 0.1 & 0.01 & 0.4 & 0.1 \\
\hline CI & $0.3-3.5$ & $0.8-9.1$ & $0.1-3.7$ & $0.4-6.7$ & $1.0-3.9$ & $0-0.8$ & $0-1.2$ & $0-0.5$ & $0-1.6$ & $0-0.6$ \\
\hline $\mathrm{n} / \mathrm{N}$ & $9 / 12$ & $4 / 4$ & $5 / 6$ & $5 / 5$ & & $3 / 11$ & $2 / 5$ & $1 / 6$ & $2 / 6$ & \\
\hline
\end{tabular}

${ }^{a}$ number of fields having crop growth problems due to surface ponded water (n)/total number of experimental fields (N)

${ }^{\mathrm{b}}$ significant difference between years, $p=0.0002$ 
Vol. 19(2010): 313-326.

stubble cultivated and direct drilled field, and the mean share of the field area with growth problems was larger in these fields than in the ploughed or grass fields. The differences were, however, not statistically significant when the data of years 2004 and 2005 was analyzed together. In years 2001, 2003 and 2005, the mean areas hampered were small compared to those in 2004, and growing problems were observed only in some fields.

\section{Discussion}

\section{Surface water ponding}

During the experimental period of five years, the surface water ponding and the signs of soil wetness in crop stand were monitored 13 times. The determination of the share of the water ponded areas to that of the total field area by using a GPS device and GIS programs was found to be a practical method for monitoring differences between various tillage treatments in the field scale in terrain conditions in areas covered by puddles, depressional water or poorly growing crop. The annual variation in the precipitation and the distribution of the rainfall affected the occurrence of ponded surface water. In most observation times, surface water ponding or signs in crop stand were found only in some fields. On the other hand, taking into account all observation times, ponded water was found three times and signs in crop stand once in more than $50 \%$ of the fields. In each of these cases, the precipitation during 1 to 4 months before the determination was clearly larger than the long-term average. According to our results, surface water ponding or crop hampering due to soil wetness occurred on clayey soils when the amount of rainfall was considerable greater than on average. In Finland, heavy rainstorms are rare (Finnish Meteorological Institute 2007). Thus, a moderate soil infiltration capacity is sufficient for avoiding surface water ponding.

We described the effect of rainfall on the surface water ponding very roughly. For more detailed examination, the rainfall should be determined dai- ly in each area or field. Likewise, more frequent surface water ponding observations would have improved the accuracy of results. In the future, automatic weather stations, located in experimental areas, can improve the accuracy of observations. Also making the observations of surface water ponding during the winter time become relevant in the future if the winters will become milder and the precipitation in the autumn and winter will increase as has been forecasted by IPCC (2007).

Surface water ponding and crop hampering due to soil wetness were used as indicators for low clayey soil infiltration capacity and near saturated hydraulic conductivity. According to our results, for such purpose, observations from a period of several years need to be available, depending on the amount and distribution of rainfall as discussed above. Also, the repeated identifications of the ponded water and crop hampering from a same field reduce the effect of the temporal variation on the result. In addition, when comparing different fields the differences in the crop sensitivity to the soil wetness as well as different soil management practices need to be taken into account. For instance, van Es et al. (1999) found that tillage and temporal factors are important sources for the variation of the infiltrability of fine textured soils.

The surface water ponding occurred usually year after year in the same areas of a field. In many fields, water gathered in the depressions, caused by old furrows, and in other uneven spots on the soil surface or in compact headland areas (see Fig. 3). The reasons for the surface water ponding or soil wetness during a growing season were, however, not evident from our data. Soil sealing and discontinuity in flow via active macroporosity are soil physical properties that are critical to the infiltration capacity and hydraulic conductivity of wet soil. Repeated surface water ponding can also be a sign of poorly operating drainage system. Complementary soil physical measurements are required to investigate reasons for the repeated surface water ponding. In the field scale, the soil quality kits (described by e.g. Kukkonen et al. 2004), may provide a practical method for examination of soil properties. 
Alakukku et al. Monitoring of surface water ponding on clayey soils

\section{Effects of tillage on surface water ponding}

Our results indicate that the infiltration capacity or the hydraulic conductivity of the wet stubble cultivated clayey soil with gentle slope were slightly lower than those of the mouldboard ploughed soil. The mean relative area of the ponded surface water, and the crop (mainly spring cereals) hampered due to soil wetness were larger in the conservation tilled fields than in the autumn mouldboard ploughed fields. The difference was, however, statistically significant only in spring 2005. Our result is in agreement with those by Lipiec et al. (2006), who found that the cumulative infiltration was reduced by $36 \%$ in shallow harrowed silt loam soil compared to mouldboard ploughed soil. Alakukku (1998) has reported that the saturated hydraulic conductivity of fine textured soils was less in the shallow stubble cultivated topsoil layer of $20 \mathrm{~cm}$ than that of mouldboard ploughed topsoil. On the other hand, Buczko et al. (2006) have reported controversy infiltration results for silty soil. The inconsistencies can be associated, for instance, with soil surface sealing (e.g. McGarry et al. 2000), temporal water storage capacity of wet soil (Alakukku 1998, Lipiec et al. 2006), tillage timing (Withers et al. 2007) and flow through active macropores made by soil fauna (Pitkänen and Nuutinen 1998).

In general, the mean relative share of the surface ponded water was less for the perennial grass than for stubble cultivated soil. The differences in the mean relative areas between the ploughed and grass covered fields varied from one measurement to the other. The water ponding determined on the surface of the field may have been underestimated especially in perennial grass fields as compared to the tilled soil. In perennial grass field, crop residue is accumulated on the soil surface forming a notable cover, which probably increases the temporal water storage in soil surface even when no visible water is recognized. On the other hand, Pietola et al. (2006) found that under dry soil conditions infiltration into tilled clay soil was lower than to an adjacent cracked soil under grass, but the difference in the infiltration rate between the tilled and grass covered soil reduced when the soil reswelled in wet conditions. Also Wienhold and Tanaka (2000) found that the infiltration rate of soil at $5 \mathrm{~cm}$ tension was higher in perennial hay than in tilled plots. The saturated hydraulic conductivity of a clayey soil, covered by perennial hay, was found by Jiang et al. (2007) to be clearly greater in the $0-10 \mathrm{~cm}$ layer than in mulch tilled soil.

Surface water ponding and low hydraulic conductivity in wet conditions increase clearly the risk for surface runoff and crop hampering due to the soil wetness. Relevant to this, Turtola et al. (2007) found that replacing mouldboard ploughing by shallow stubble cultivation or grass cover increases the proportion of the surface runoff from the total runoff from 16 to 44 or $60 \%$, respectively, in a gently sloping clayey soil having low saturated hydraulic conductivity. In 2004, the spring cereal yields in areas hampered due to the surface water ponding were evidently very small and in several places the crops failed. This is in accordance with Pitkänen (1994) and Alakukku et al. (2009), who found that in clayey soils the spring cereal yields were lower in stubble cultivated or direct drilled fields when the precipitation of June was clearly larger than the long-term average. Arshad et al. (1999) reported similar results for barley cultivation in a silty loam soil in a cold, semiarid region of Canada.

\section{Conclusions}

A GPS devise was found to be a simple technique to locate and monitor the spatial and temporal variations in areas of surface ponded water or poorly growing crop.

Surface water ponding or crop hampering due to soil wetness occurred in clayey soils when the amount of rainfall was clearly larger than the longterm average. Thus, observations from a period of several years and/or several times during a year are needed for reliable determinations of differences between different soil management practices. 
Vol. 19(2010): 313-326.

Surface water ponding and crop hampering due to soil wetness are indicators for low clayey soil infiltration capacity and hydraulic conductivity close to saturation. Surface water ponding and low hydraulic conductivity of soil in wet conditions increase clearly the risk for surface runoff. However, complementary soil physical measurements are required to investigate the reasons for repeated surface water ponding.

Acknowledgements. Financial support from the Ministry of Agriculture and Forestry is gratefully acknowledged. We acknowledge the assistance of Juha Eskelinen and MarjaLiisa Westerlund in the fields. We are grateful to Risto Mäki from the Finnish Environment Institute for supplying the groundwater table data, and Anneli Nordlund and Pirkko Karlsson from the Finnish Meteorological Institute for delivering the weather data, and Berit Mannfors for revising the language.

\section{References}

Alakukku, L. 1998. Properties of compacted fine-textured soils as affected by crop rotation and reduced tillage. Soil \& Tillage Research 47: 83-89.

Alakukku, L., Ristolainen, A. \& Salo, T. 2009. Grain Yield and Nutirent Balance of Spring Cereals in Different Tillage Systems. In: Proceedings of ISTRO $18^{\text {th }}$ Triennial Conference 'Sustainable Agriculture'. June 15-19, 2009, Izmir, Turkey . CD-ROM. T6-005-1-T6-005-7.

Arshad, M.A., Franzluebbers, A.J. \& Azooz, R.H. 1999. Component of surface soil structure under conventional and no-tillage in northwestern Canada. Soil \& Tillage Research 53: 41-47.

Ball, B.C., Crichton, I. \& Horgan, G.W. 2008. Dynamics of upward and downward $\mathrm{N}_{2} \mathrm{O}$ and $\mathrm{CO}_{2}$ fluxes in ploughed or no-tilled soils in relation to water-filled pore space, compaction and crop presence. Soil \& Tillage Research 101:20-30.

Berry, J.J. 1997. The simulation approach to analyzing the nonparametric randomized complete block design. Observations: The Technical Journal for SAS Software Users 6: 36-45.

Buczko, U., Bens, O. \& Hüttl, R.F. 2006. Tillage effects on hydraulic properties and macroporosity in silty and sandy soils. Soil Science Society of American Journal 70: 1998-2007.

Drebs, A., Nordlund, A., Karlsson, P., Helminen, J. \& Rissanen, P. 2002. Climatological statistics of Finland 19712000. Finnish Meteorological Institute, Helsinki.

Dunn, G.H. \& Phillips, R.E. 1991. Macroporosity of a welldrained soil under no-till and conventional tillage. Soil Science Society of American Journal 55: 817-823.
Finnish Meteorological Institute. 2007. Rankka sade, paljonko sataa ja miten pitkän ajan sisällä. Cited 10 July 2007. Available on the Internet: http://www.fmi.fi/saa/ tilastot_38.html. (In Finnish)

FAO 1998. World Reference Base for Soil Resources. Word Soil Resources Report 84. FAO, Rome, Italy.

Gantzer, C.J. \& Blake, G.R. 1978. Physical characteristics of Le Sueur clay loam soil following no-till and conventional tillage. Agronomy Journal 70: 853-857.

Hamza, M.A. \& Anderson, W.K. 2005. Soil compaction in cropping systems. A review of the nature, causes and possible solutions. Soil \& Tillage Research 82: 121-145.

IPCC. 2007. Climate Change 2007: Synthesis Report. 52 p. Cited 10 July 2009. Available: http://www.ipcc.ch/pdf/ assessment-report/ar4/syr/ar4_syr.pdf

Jiang, P., Anderson, S.H., Kirchen, N.R., Sadler, E.J. \& Sudduth, K.A. 2007. Landscape and conservation management effects on hydraulic properties of a claypansoil toposequence. Soil Science Society of American Journal 71: 803-811.

Kenward, M.G. \& Roger, J.H. 1997. Small sample inference for fixed effects from restricted maximum likelihood. $\mathrm{Bi}$ ometrics 53: 983-997.

Koskiaho, J., Kivisaari, S., Vermeulen, S., Kauppila, R., Kallio, K. \& Puustinen, M. 2002. Reduced tillage: Influence on erosion and nutrient losses in a clayey field in southern Finland. Agricultural and Food Science in Finland 11: 37-50.

Kuehl, R.O. 2000. Design of Experiments: Statistical Principles of Research Design and Analysis, $2^{\text {nd }}$ edition. Pacific Grove, CA: Duxbury.

Kukkonen, S., Alakukku, L., Myllys, M. \& Palojärvi, A. 2004. Maan laadun arviointi tiloilla - Kirjallisuuskatsaus. Soil quality on-farm assessment - a review. Maa- ja elintarviketalous 63: 86 p. Cited 10 July 2007. Available: http://www.mtt.fi/met/pdf/met63.pdf (In Finnish with English summary)

Lilja, H., Uusitalo, R., Yli-Halla, M., Nevalainen, M., Väänänen, T. \& Tamminen, P. 2006. Suomen maannostietokanta. Soil maps at scale 1:250,000 and properties of soil, MTT:n selvityksiä 114: 1-69. (In Finnish with English summary)

Lipiec, J., Kuś, J., Słowińska-Jurkiewicz, A. \& Nosalewicz, A. 2006. Soil porosity and water infiltration as influenced by tillage methods. Soil \& Tillage Research 89: 210-220.

McGarry, D., Bridge, B.J. \& Radford, B.J. 2000. Contrasting soil physical properties after zero and traditional tillage of an alluvial soil in the semi-arid subtropics. Soil \& Tillage Research 53: 105-115.

Ministry of Agriculture and Forestry 2004. Horisontaalisen maaseudun kehittämisohjelman väliarviointi. Manner-Suomi. MMM:n julkaisuja 1/2004. 273 p. + 27 app. (In Finnish with English summary)

Pietola, L., Rasa, K., Räty, M., Uusi-Kämppä, J., Yli-Halla, M., Horn, R., \& Tippkötter, R. 2006. Management-induced changes of soil physical properties in vegetated buffer zones. In: Horn, R., Fleige, H., Peth, S. \& Peng, X. (eds.). Soil Management for Sustainability. Advances in Geoecology 38: 301-308.

Pitkänen, J. 1994. A long-term comparison of ploughing and shallow tillage on the yield of spring cereals in Finland. Proceedings 13th International Conference International Soil Tillage Research Organization, Aalborg, 


\section{AGRICULTURAL AND FOOD SCIENCE}

\section{Alakukku et al. Monitoring of surface water ponding on clayey soils}

Denmark. July 24-29 1994. Volume II: 709-715.

Pitkänen, J. \& Nuutinen, V. 1998. Earthworm contribution to infiltration and surface runoff after 15 years of different soil management. Applied Soil Ecology 9: 411-415.

Puustinen, M., Koskiaho, J. \& Peltonen, K. 2005. Influence of cultivation methods on suspended solids and phosphorus concentrations in surface runoff on clayey sloped fields in boreal climate. Agriculture, Ecosystems \& Environment 105: 565-579.

Puustinen, M., Tattari, S., Koskiaho, J. \& Linjama, J. 2007. Influence of seasonal and annual hydrological variations on erosion and phosphorus transport from arable areas in Finland. Soil and Tillage Research 93: 44-55.

Skøien, S. 1988. Soil erosion and runoff losses of phosphorus, effect of tillage and plant cover. Norsk landbruksforskning 2: 207-218.

Soveri, J., Mäkinen, R. \& Peltonen, K. 2001. Pohjaveden korkeuden ja laadun vaihteluista Suomessa 1975-1999. Suomen ympäristö 420. 382 p. (In Finnish with English summary).

Starr, J.L. 1990. Spatial and temporal variation of ponded infiltration. Soil Science Society of American Journal 54: 629-636.

Stepniewski, W. \& Łabuda, S. 1989. The influence of 10 days' flooding in seven development stages of spring barley on its growth, yield, and N, P, K content and uptake. Part I. Growth and yield. Polish Journal of Soil Science 22: 93-99.

Tebrügge, F. \& Düring, R.-A. 1999. Reducing tillage intensity - a review of results from a long-term study in Germany. Soil \& Tillage Research 53: 15-28.

Turtola, E., Alakukku, L., Uusitalo, R. \& Kaseva, A. 2007. Surface runoff, subsurface drainflow and soil erosion as affected by tillage in a clayey Finnish soil. Agricultural and Food Science 16: 332-351.

Turtola, E. \& Jaakkola, A. 1995. Loss of phosphorus by surface runoff and leaching from a heavy clay soil under barley and grass ley in Finland. Acta Agriculturae Scandinavica 45: 159-165.

Turtola, E. \& Paajanen, A. 1995. Influence of improved subsurface drainage on phosphorus losses and nitrogen leaching from a heavy clay soil. Agricultural Water Management 28: 259-310.

Ulén, B. 1997. Nutrient losses by surface run-off from soils with winter cover crops and spring-ploughed soils in the south of Sweden. Soil \& Tillage Research 44: 165-177.

Van Es, H.M., Ogde, C.B., Hill, R.L., Schindelbeck, R.R. \& Tsegaye, T. 1999. Integrated assessment of space, time, and management-related variability of soil hydraulic properties. Soil Science Society of American Journal 63: 1500-1608.

Wienhold, B.J. \& Tanaka, D.L. 2000. Haying, tillage, and nitrogen fertilization influences on infiltration rates at a Conservation Reserve Program site. Soil Science Society of American Journal 64: 379-381.

Withers, P.J.A., Hodgkinson, R.A., Bates, A. \& Withers, C.L. 2007. Soil cultivation effects on sediment and phosphorus mobilization in surface runoff from three contrasting soil types in England. Soil \& Tillage Research 93: 438-451.

Yli-Halla, M., Mokma, D., Peltovuori, T. \& Sippola, J. 2000. Suomalaisia maaprofiileja. Agricultural soil profiles in Finland and their classification. Maatalouden tutkimuskeskuksen julkaisuja. Sarja A 78, 105 p. (In Finnish with English Summary) 